\title{
5G TECHNOLOGIES AND BUSINESS ASPECTS: HIGH-LEVEL POINT OF VIEW
}

\author{
Ivan Petrov ${ }^{1}$, Toni Janevski² \\ ${ }^{I}$ Makedonski Telekom AD. Skopje, Republic of North Macedonia \\ ${ }^{2}$ Faculty of Electrical Engineering and Information Technologies, \\ "Ss. Cyril and Methodius" University in Skopje, \\ P.O. box 574, 1001 Skopje, Republic of North Macedonia \\ tonij@feit.ukim.edu.mk
}

\begin{abstract}
A b s tra ct: This paper covers technological and business aspects of $5 \mathrm{G}$ mobile networks at their initial targeted year for acceptance, 2020. It gives a high level view beyond 5G, toward the next generation which is referred to here as 6G. The 5G introduces New Radio (NR) in sub-6 GHz bands and also in $\mathrm{mm}$ Wave bands above $24 \mathrm{GHz}$. The paper analyzes $5 \mathrm{G}$ novelties such as network function virtualization and network softwarization, which means that $5 \mathrm{G}$ Next Generation Core and 5G NR access network are built by using different functions in split user and control planes. That provides the basis for the network slicing approach, with three main service types defined for the 5G era: enhanced Mobile Broadband (eMBB), massive Machine Type Communication (mMTC) and Ultra-Reliable Low-Latency Communication (URLLC), which may be provided via separate network slices as logically separated network partitions. Considering the $5 \mathrm{G}$ business aspects, the paper states that the initial $5 \mathrm{G}$ driver is eMBB, then follows mMTC, and last to be deployed is the most demanding one, the URLLC. Finally, with many $5 \mathrm{G}$ network functions, also exposed to the third parties such as Over-The-Top (OTT) service providers, with constantly increasing volume of traffic and number of connected devices, this paper also includes future use of Machine Learning and generally Artificial Intelligence (AI) is becoming necessity for further expansion of the mobile world beyond 5G, toward the 6G in 2030s.
\end{abstract}

Key words: 5G; 6G; mobile networks; mobile business; mobile technologies

\section{G -ТЕХНОЛОГИИТЕ И ДЕЛОВНИТЕ АСПЕКТИ: ПОГЛЕД ОД ПОВИСОКА ГЛЕДНА ТОЧКА}

А п с т р а к т: Овој труд ги опфаќа технолошките и деловните аспекти на мобилните мрежи од 5-та генерација (5G) во нивната таргетирана година за прифаќање, 2020. Дава поглед од повисока гледна точка преку 5G, кон следната генерација која е референцирана како 6G. 5G вклучува New Radio (NR) во фреквенциски подрачја под $6 \mathrm{GHz}$, како и во милиметарските опсези над $24 \mathrm{GHz}$. Трудов исто така ги анализира новитетите па 5G како што се мрежната виртуелизација и мрежната софтверизација, што значи дека 5G Next Generation Core и пристапната мрежа 5G NR се направени со користење на различни фунции во поделените корисничка и контролна рамнина. Оваа поделба ја обезбедува основата за мрежно разделување, со три главни сервисни типа дефинирани за ерата на 5G: подобрен мобилен широкопојасен пристап (eMBB), масивна комуникација меѓу машини (mMTC) и високонадежни комуникации со многу мали доцнења (URLLC), коишто можат да бидат овозможени преку посебни мрежни парчиња (slices) како логички издвоени мрежни делови. Имајќи ги предвид деловнис аспекти на 5G, трудов тврди дека иницијален двигател на 5G ќе биде еMBВ, потоа следува mМТС, и последниот сервисен тип кој ќе биде имплементиран и кој има најголеми побарувања во однос на перформансите е URLLC. Конечно, со многу мрежни функции на 5G, кои ќе бидат отворени и достапни и до трети страни како што се сервисните провајдери ОТТ (Over The Top), со постојано зголемување на волуменот на сообраќај и бројот на поврзани уреди, во овој труд исто така се заклучува дека идните употреби на машинското учење и вештачката интелигенција (AI) општо стануваат потреба за понатамошна експанзија на мобилниот свет и по 5G, кон 6G во 2030-тите години.

Клучни зборови: 5G; 6G; мобилни мрежи; мобилен бизнис; мобилни технологии 


\section{INTRODUCTION}

Each new mobile generation offers improved and advanced features compared to its predecessor.

However, mobile technologies evolution is based on so-called generations which include [1-3]:

- $1 \mathrm{G}$ (First Generation): It is the only analogue mobile generation, based on FDMA (Frequency Division Multiple Access), used in 1980s. It is not used anymore.

- $2 \mathrm{G}$ (Second Generation): It is the first digital mobile generation, based mainly on TDMA (Time Division Multiple Access) and FDMA, with GSM (Global System for Mobile communications) as the most known representative.

- 3G (Third Generation): It is the first generation of mobile systems which included by default the Packet Switched (PS) domain, mainly for public Internet access in parallel with CS (for voice and SMS). The radio interface in $3 \mathrm{G}$ was based on WCDMA - Wideband Code Division Multiple Access (coupled with TDMA/FDMA), in radio part. The requirements for $3 \mathrm{G}$ were set by the
ITU in the umbrella specification IMT-2000. 3G initially started at the beginning of 2000s.

- 4G (Fourth Generation): This is a generation which is all-IP by default in access and core parts, where access part is based on OFDMA (Orthogonal Frequency Division Multiple Access) with LTE (Long Term Evolution) standards from 3GPP being the dominant ones. It started around 2010.

- 5G (Fifth Generation): It is the last standardized generation of mobile systems (the first 5G standard, 3GPP Release 15, is frozen in June 2019), which increases the data rates of $4 \mathrm{G}$ by more than 10 times with new radio interface called NR (New Radio) and allocation of new spectrum, providing possibilities for many new emerging services in different verticals. The $5 \mathrm{G}$ decade is 2020 s.

In each next mobile generation the speed (i.e. bitrate) is increasing, and the latency (i.e. delay) is decreasing (Table 1), and such trend is not going to change toward the $6 \mathrm{G}$ (the foreseen next mobile generation after the $5 \mathrm{G}$ ).

Table 1

Mobile evolution vs. speed and latency [4]

\begin{tabular}{lccccc}
\hline \hline & $1 \mathrm{G}$ & $2 \mathrm{G}$ & $3 \mathrm{G}$ & $4 \mathrm{G}$ & $5 \mathrm{G}$ \\
\hline Approximate deployment date & $1980 \mathrm{~s}$ & $1990 \mathrm{~s}$ & $2000 \mathrm{~s}$ & $2010 \mathrm{~s}$ & $2020 \mathrm{~s}$ \\
Theoretical download speed & $2 \mathrm{kbit} / \mathrm{s}$ & $384 \mathrm{kbit} / \mathrm{s}$ & $56 \mathrm{Mbit} / \mathrm{s}$ & $1 \mathrm{Gbit} / \mathrm{s}$ & $10 \mathrm{Gbit} / \mathrm{s}$ \\
Latency & N/A & $629 \mathrm{~ms}$ & $212 \mathrm{~ms}$ & $60-98 \mathrm{~ms}$ & $<1 \mathrm{~ms}$ \\
\hline \hline
\end{tabular}

\section{G (FIFTH GENERATION) IN SHORT}

The requirements for $5 \mathrm{G}$ are specified in IMT2020 (a.k.a. 5G) by the ITU, [4-6]. According to them, latency in the air link (5G New Radio) should be lower than $1 \mathrm{~ms}$ (for certain critical services), end-to-end (device to core) latency to be lower than $10 \mathrm{~ms}$, connection density to be $100 \times$ compared with LTE, area capacity density to be $1 \mathrm{Tbit} / \mathrm{s} / \mathrm{km}^{2}$, system spectral efficiency to be $10 \mathrm{bit} / \mathrm{s} / \mathrm{Hz} / \mathrm{cell}$, peak throughput (downlink) per connection to be $10 \mathrm{Gbit} / \mathrm{s}$ and energy efficiency to be $>90 \% \mathrm{im}$ provement over LTE.

5G uses OFDMA/SCFDMA in uplink and downlink with different numerologies (the NR is in fact extension of the LTE radio interface), and provides full support of beamforming in spectrum of 0.4 up to $90 \mathrm{GHz}$ and carrier bandwidth of up to 100
$\mathrm{MHz}$ in sub- $6 \mathrm{GHz}$ bands (and $400 \mathrm{MHz}$ for bands above $24 \mathrm{GHz}$, the mmWave bands). The $5 \mathrm{G}$ extends further the efficiency of radio access by using higher order MIMO (e.g., $64 \times 64,128 \times 128$ ) and higher order modulation and coding schemes. The $5 \mathrm{G}$ base stations are called gNodeBs, and have the same architectural aspect as eNodeBs in 4G (being connected between themselves and with the core), with further split of Control Plane (CP) and User Plane (UP) functions.

High-level view of $5 \mathrm{G}$ network architecture is presented in Figure 1 and Figure 2. One may notice unification of all known access technologies with enhanced fronthaul and backhaul networks. Unlike $4 \mathrm{G}$ networks which use gateway nodes (e.g. Serving Gateway - S-GW, Packet Data Network Gateway P-GW), 5G defines many functions that can be combined together for provision of different functional- 
ities in user, control and management planes (Figure 1). That is referred to as network softwarization and virtualization, based on SDN (Software Defined Networking) and NFV (Network Function Virtualization), illustrated in Figure 2 as a high level view (details are already known in 3GPP Release 15 [712]). This leads to network slicing approach, which is in fact provision of logically isolated network parts, targeted to different group of services. However, network slicing is just another term for LINPs (Logically Isolated Network Partitions) which were defined in NGN (Next Generation Networks) umbrella standards by the ITU, [3]. Network slice can provide functionality of complete network including radio access network and core functions. One $5 \mathrm{G}$ mobile network can support one or several network slices. 5G systems should enable users to obtain services from more than one network slice simultaneously.

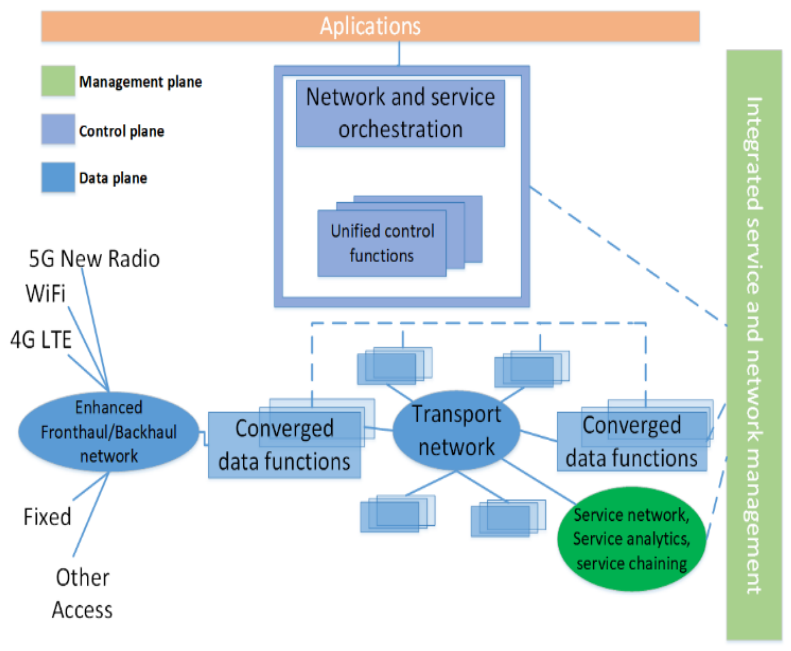

Fig. 1. Network architecture for IMT-2020/5G

\section{Applications and services with various requirements}

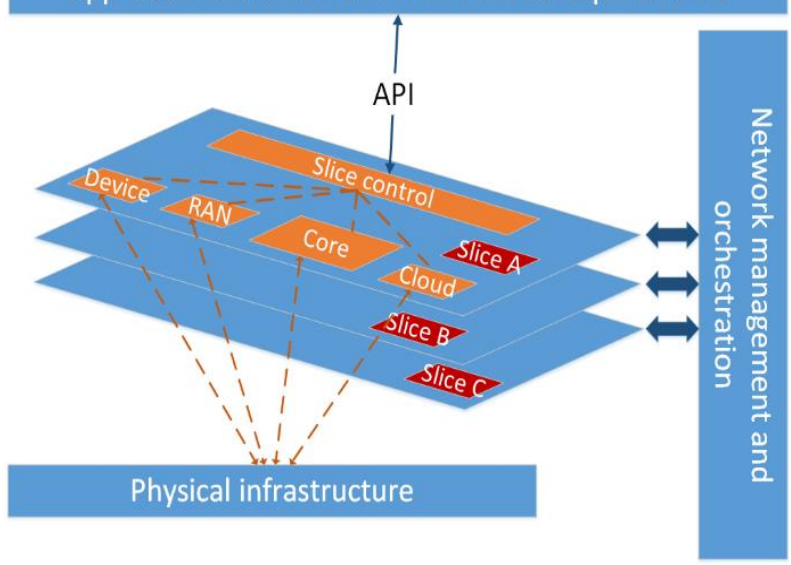

Fig. 2. Network softwarization view of IMT-2020/5G
3GPP defines two types of 5G network architectures: Stand-Alone (SA) and Non Stand-Alone (NSA), which should be accepted as main 5G standards by the ITU in February 2020.

Non-Stand-Alone (NSA) network architecture (Figure 3) is a concept that allows operators to deploy $5 \mathrm{G}$ cells that will depend entirely on existing LTE network for all control functions and add-on services. This concept works in master-slave structure where $4 \mathrm{G}$ access node (eNodeB) is the master and $5 \mathrm{G}$ access node ( $\mathrm{gNodeB}$ ) is the slave.

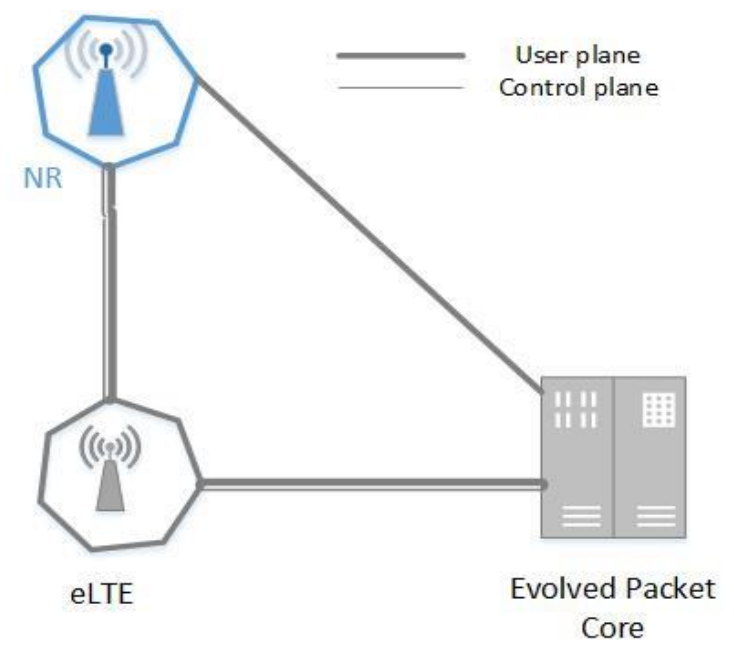

Fig. 3. 5G NSA architecture

On the other side, 5G Stand-Alone (SA) architecture (Figure 4) means that independent $5 \mathrm{G}$ network is implemented including both New Radio (NR) in the access part and 5G Core (5GC). This architecture model provides end to end $5 \mathrm{G}$ user experience directly used by $5 \mathrm{G}$ device. However, the 5G SA architecture also interoperates with existing 4G LTE mobile networks to provide service continuity especially at areas that are not covered with $5 \mathrm{G}$ (which is the usual case for each new mobile generation when it starts with the commercial deployments) providing connectivity for both $5 \mathrm{G}$ users and non-5G users (e.g. 4G).

Both 5G architectures NSA and SA have their advantages depending upon the observing perspective. From technological and business points of view the NSA provides clear win on the $5 \mathrm{G}$ "scene" for the 3GPP regarding the $5 \mathrm{G}$ standards, because NSA establishes in fact smooth evolution from LTE /LTE-A/LTE-A Pro (4G standards from 3GPP), which have become the dominant $4 \mathrm{G}$ mobile technologies in 2010s (the second 4G standard, Mobile WiMAX 2.0, is decaying and disappearing). 


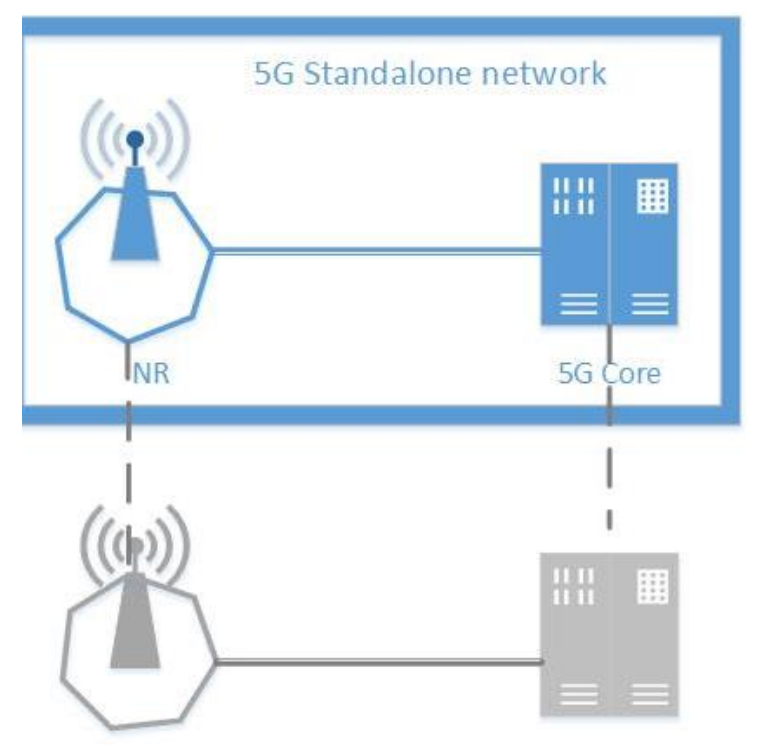

LTE eNB

Evolved Packet

Fig. 4. 5G SA architecture

Although there are also 5G proposals from other countries, it is undoubted that $5 \mathrm{G}$ standard from 3GPP (in both NSA and SA modes) will be in fact the unified new mobile generation (something similar that happened in the past with Ethernet or WiFi standards from IEEE, which are also unified standards in the LAN segments).

The core network in SA is 5G Next Generation Core (it is used interchangeably with 5G Core in this paper) while in NSA it is initially 4G EPC (Evolved Packet Core) or 5G Core. One may say that SA provides high performance $5 \mathrm{G}$ environment while NSA leverages the existing $4 \mathrm{G}$ deployments. However, today (in year 2020) telecom operators (i.e. telcos) introduce the $5 \mathrm{G}$ network functionalities with the NSA. Both deployment strategies have as the final goal the deployment of standalone $5 \mathrm{G}$ network. One of the main moves towards that end goal is optimizing $5 \mathrm{G}$ investment and achieving near-soon market leadership position in new verticals (e.g. industry 4.0 , various smart services, automotive industry for vehicle to anything communication, i.e. V2X and so on). The time scale of $5 \mathrm{G}$ deployments is directly influenced by the availability of sub- $6 \mathrm{GHz}$ spectrum bands for enhanced Mobile Broadband (eMBB) services (which are the expected front "runner" for the 5G), availability of affordable 5G handsets which support the $5 \mathrm{G}$ bands as defined by the ITU's WRC (World Radiocommunication Conference) 2019, as well as user adoption of 5G technology (which is mainly driven by the telcos and end-user equipment availability and process), and operator's ability to deploy nationwide $5 \mathrm{G}$ coverage.

End to end $5 \mathrm{G}$ requires new architecture, with $\mathrm{NR}$ in the access part and 5G Core. However, the evolution from $4 \mathrm{G}$ to $5 \mathrm{G}$ starts from the LTE networks with add-ons of $5 \mathrm{G}$ compatible functionalities such as dynamic experience management, self organizing network and analytic driven orchestration.

\section{THE 5G EVOLUTION}

Figure 5 shows step-by-step migration scenario from $4 \mathrm{G}$ LTE towards $5 \mathrm{G}$. Today we have LTE core and radio access networks. Step 1 is to add 5G radio in dual connectivity mode with LTE as an anchor. This architecture provides LTE core plus $5 \mathrm{G}$ compatible functionality. $5 \mathrm{G}$ control plate is established via LTE while $5 \mathrm{G}$ user plane is provided via LTE or directly via 5G NR. Next step is to assure $5 \mathrm{G}$ core network and standalone $5 \mathrm{G}$ radio accesses without need for an LTE anchor. This approach provides distributed radio and core architecture required to deliver low latency. The aim is to evolve from today's silos to cognitive network built for automation. Today's legacy networks are consisted of many silos and complex automation that's why we need consolidation that offers integrated analytics, management, orchestration and dynamic experience management. Dynamic experience management refers to automated Quality of Experience (QoE) optimization of each application session with fully automated management orchestration based on use of Artificial Intelligence (in fact, that is Machine Learning).
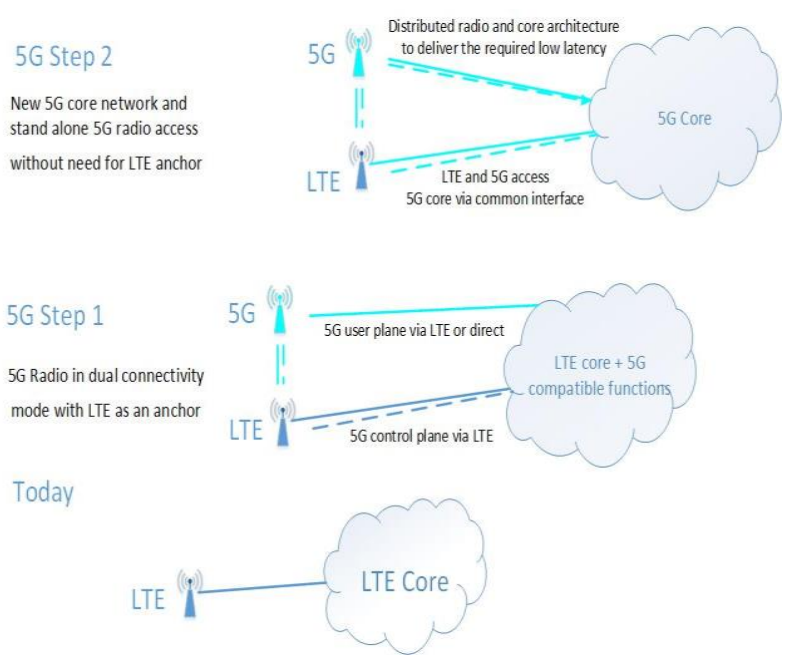

Fig. 5. 4G to 5G evolution steps 
One has to point to the evolution of $5 \mathrm{G}$ network slicing which is available also in $4.9 \mathrm{G}$ networks. Network slice represents composition of adequately configured network functions, network applications and underlying cloud infrastructure, physical access and core network resources and virtual (or emulated) resources that are bundled together to meet the requirements of specific use case with predefined bandwidth, latency, processing and resiliency coupled with a business purpose. Network slicing must enable flexible creation, placements of network functions to assure separate manageability on per slice basis that enable flexible partitioning and sharing of radio resources in the 5G RAN (radio Access Network) as well as 5G Core network. 5G network slicing assures each slice to be tailored to a specific use case that enables mobile network as a service business model.

In order to deliver best QoE by steering traffic across multiple air interfaces and also using multiple air interface aggregation (e.g., 3GPP has introduced the WiFi carrier and LTE carrier aggregation even in pre-5G releases).

Figure 6 illustrates multi access environment with aggregation on protocol layer 4 (with TCP Transmission Control Protocol). Just for comparison purposes, LTE-Advanced has introduced aggregation on layer 3 by having protocol layers 1 and 2 to be different on different frequency carriers which are being aggregated. One possibility for aggregation on layer 4 is with Multipath TCP (MPTCP) which is still in information and draft forms at the IETF, [13], while the SCTP (Stream Control Transmission Protocol) is currently the default transport protocol in control plane between nodes in $4 \mathrm{G}$ and $5 \mathrm{G}$ core networks (one may mention also HIP Host Identity Protocol, which is also another experimental protocol, from the IETF, which provides multihoming, by placing itself between the network layer, i.e. IP, and transport layer protocol). It allows all bands to aggregate and utilize effectively with flexible policy control. MPTCP allows seamless integration and operation of 5G NR access and other access networks connected to the $5 \mathrm{G}$ core. For control of multiple access networks there is required intelligent network controlled traffic steering. Mobile user equipment connects to $\mathrm{WiFi}, 4 \mathrm{G}$ or $5 \mathrm{G}$ access nodes and multipath manager in cloud connects to the mobile client (the user equipment - UE) and instantiates the multi-link scheduler function in the network, splitting the user traffic over the $\mathrm{WiFi}, 4 \mathrm{G}$ and $5 \mathrm{G}$ paths and aggregating the traffic at the UE (in the downlink direction), and vice versa in the uplink (by using the 5G QoS flow based approach with reflection of the downlink setup also in the uplink).

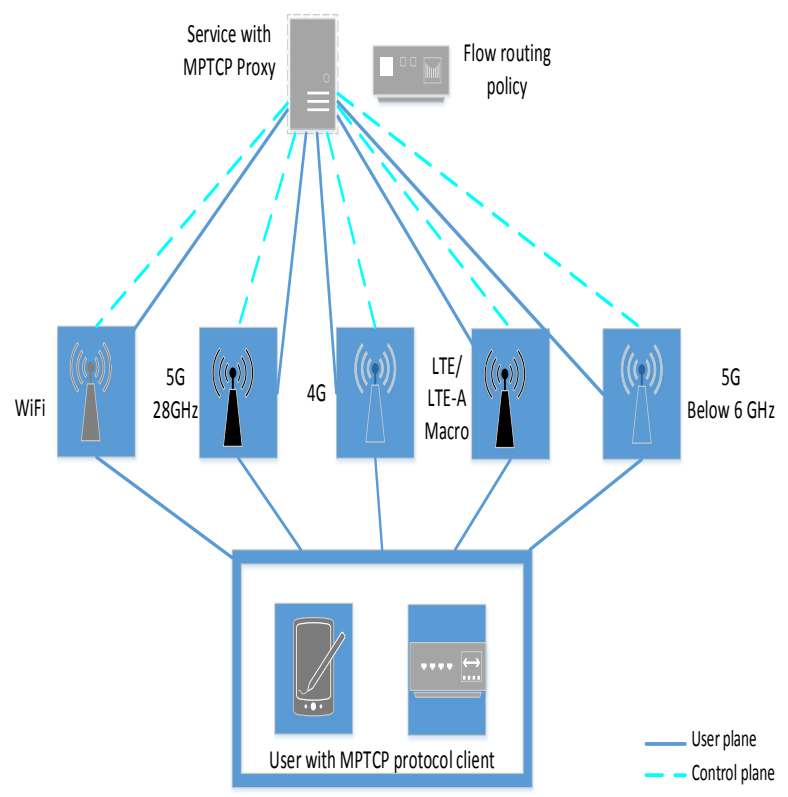

Fig. 6. Multiple accesses aggregation and load balancing

\section{SOME 5G EXPECTATIONS}

It is expected $5 \mathrm{G}$ to build trusted and secure application and service ecosystems based on machine learning, converged edge cloud, multi technology access and to promote openness like open APIs (Application Programming Interfaces), open source software for the hardware, and developing $5 \mathrm{G}$ applications open source communities. In later stages of 5G deployments (e.g. after 2025) [14-15], $5 \mathrm{G}$ enhancements are tailored toward lower latencies, such as latencies up to $5 \mathrm{~ms}$ that should assure process automation (in industry) with help of mission critical sensors. Also, AR (Augmented Reality), VR (Virtual Reality) and generally speaking XR (Any Reality), require high bandwidth, secure and very low latency communications (especially AR). On the other side, the expectations of mobile trends, [14], is that the video is the dominant type of traffic in all environments, fixed and mobile ones.

Overall, around $70-75 \%$ of all IP traffic in public Internet including also managed IP networks (which are normally isolated from the public Internet, with guaranteed QoS), is video traffic. One may expect, with eMBB networks slices in $5 \mathrm{G}$, video traffic even further to increase its traffic shares due to expectations of larger data caps in mobile networks with 5G (in 2020s) and higher resolutions of the video (e.g. $2 \mathrm{k}, 4 \mathrm{k}, 8 \mathrm{k}$ video). 
One of the key expectations from $5 \mathrm{G}$ (due to its much larger bandwidth) is to promote fixed wireless access to home (FWA) via 5G in all areas with none or very low fiber penetration. On the other side $5 \mathrm{G}$ hotspots is expected to provide AR/VR streaming from different events to user devices. We can notice that different service request different SLA and network capabilities.

$5 \mathrm{G}$ Core is designed to be cloud native based on many functions in user plane and control plane. It is expected to support ultra-reliable low latency communications and massive machine type communication. 5GC enables new level of service quality especially notable with network slicing capability, and it is something that can help the operators to enter new markets (i.e. new verticals).

Figure 7 shows a high level view of $5 \mathrm{G}$ architecture and one can notice universal adaptive core that provide unified authentication and access con- trol, unified session and mobility mgmt, unified user plane.

Cloud strategy is assured with logically centralized state and user data layer for cloud ready operations established with help of shared data layer meaning that all data will be in one plane which is cloud optimized. The RESTful API, [8], in 5G core is intended to provide programmability of $5 \mathrm{G}$ networks in the similar manner as socket API provides that to applications in Operating System (OS) of a single machine.

Such APIs will be possible to be used for docking the OTT services over the mobile operator's networks, thus providing possibility for QoS-enabled provision of some such services to the end-users via different network slices, which in such case will not be part of the global Internet for which the network neutrality rules are in force. That means also - the mobile business logic will not be locked by the $5 \mathrm{G}$ equipment vendors.
Universal Adaptive Core

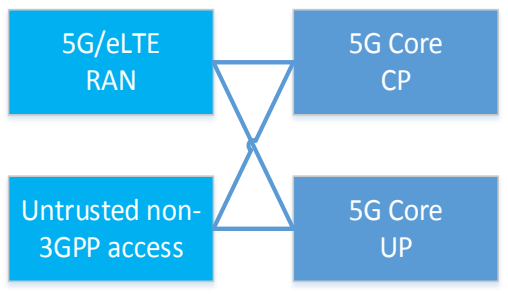

Unified authentication and access control

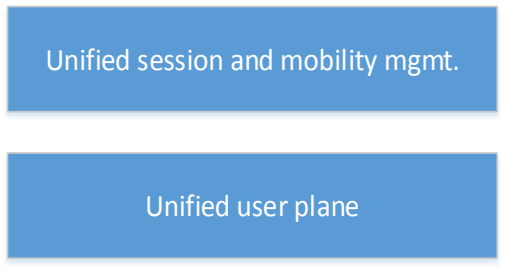

Access-agnostic core for seamless user experience
Flexible traffic handling

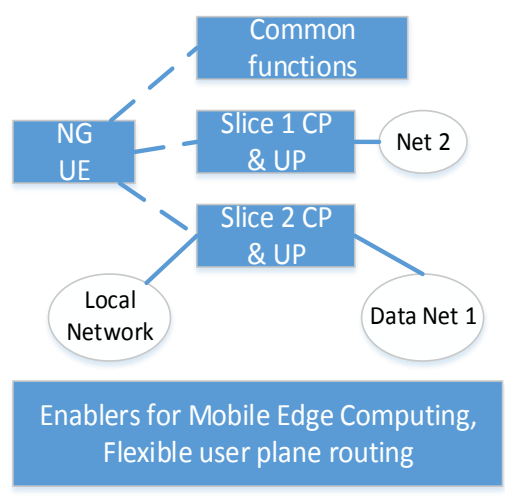

E2E Network Slicing with UE

Connecting to multiple slices

Any PDU, flexible flow based QoS Framework

Support for diverse use cases
Network functions and exposure

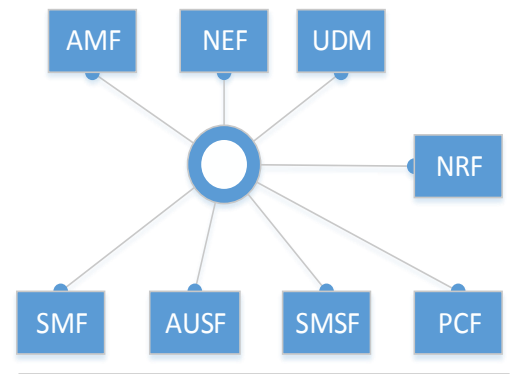

Service based control plane Architecture with network functions

Separation of data control and user planes

Shared data layer and exposure of network capabilities

Extreme Flexibility and Automation

Fig. 7. 5G architecture high level view

\section{G BUSINESS ASPECTS}

Considering the business aspects of the mobile operators, there is continuous need for revenue growth. However, the growth can be accomplished while there is still room for attracting mobile users to mobile broadband. With higher penetration of mobile broadband users, the growth decreases because there is less new users that can join (when most will become mobile broadband users).

The 4G contributed to higher level of mobile broadband, targeted to mobile Internet access service which is mainly used for access to various OTT (Over The Top) services, such as Web, email, social 
networking (e.g., Facebook, etc.), OTT voice (e.g., Viber, Skype, WhatsApp, etc.), OTT video on demand (e.g., Youtube) and video streaming, OTT cloud services (e.g., from Google, Amazon, Microsoft, Apple, etc.). Overall, the mobile broadband business is saturating horizontally (i.e., regarding new individual users), so there are needed new sources for revenues. Such new revenue sources for larger growth of mobile sector are directed towards digitalization of all segments of the public life, public administration and industry. Then, such expansion of the mobile markets is referred to as entering into vertical markets.

Overall, mobile operators may achieve larger growth by focusing on several steps in the value chains, such as digitization of the manufacturing industry, digitization of previously non-digital industries as new business models and new possibilities for mobile operators. Non-ICT industries do not have the required capacity neither experience to provide the given services by themselves. So, the digitization on initially non-digital industries is providing possibility to telecom operators to include themselves into the new business models and value chain.

Regarding the capabilities of $5 \mathrm{G}$ mobile networks and the digitization of non-ICT sectors there are three main use case business scenarios, which include the following [16-18]:

- Massive machine-type communications (mMTC): This is intended for use of massive IoT (Internet of Things) via 5G mobile network (e.g. sensor networks, capillary networks, etc.). One should note that the cellular IoT is not invented with $5 \mathrm{G}$, it exists in all mobile generations (from $2.5 \mathrm{G}$ such as GSM/GPRS, in $3 \mathrm{G}, 4 \mathrm{G}$ and it is getting the massive approach with LTEAdvanced Pro and 5G deployments). The market scenario is using a large scale low power devices (e.g., sensors, meters, etc.) at offices, homes, companies, public places, etc. Example business scenarios are smart meters, smart agriculture, logistics, tracking, fleet management, etc.

- Critical machine-type communication: This is based on URLLC in 5G, which is targeted to mission critical services, such as discrete automation (in industry), driverless vehicles and drones, and so on. Typically, these services require very low delays (e.g. below $10 \mathrm{~ms}$ or below $5 \mathrm{~ms}$ end-to-end) and very high reliability. Such low delays are possible only in upper frequency bands due to numerologies used at
mmWave bands, and with resource allocation per OFDM symbol (not per time slot, as it was the main approach in the past mobile generations). One may note that such delays can not be provided on the global scale due to limitations of transfer speed of signals by the speed of the light, which is up to $3 \times 10^{8} \mathrm{~m} / \mathrm{s}$, hence URLLC services must be provided via separate network slices which will serve private managed IP networks (of course, not part of the public Internet) that can be provided on demand by $5 \mathrm{G}$ operators to different business players in different industries (e.g., automotive industry). However, one may expect URLLC services to have certain impact on the 5G mobile business later in 2020s. Foreseen business scenarios for URLLC (also referred to as critical IoT) are industrial application and control, traffic safety and control, remote manufacturing, remote surgery, driverless vehicles (e.g. V2X - Vehicle to Anything communication), etc.

- Enhanced Mobile Broadband (eMBB) targets the traditional individual mobile users who were using mobile broadband access (mainly for access to different OTT services provided over the Internet) also before the appearance of the $5 \mathrm{G}$ (e.g., in 3G, 4G networks). This use case scenario of $5 \mathrm{G}$ is expected to be the initial driver for the 5G, together with FWA as the second main driver. What mobile users may expect with $5 \mathrm{G}$ access to the Internet? Well, that is higher speeds and lower latencies, which increases the user experience (i.e., QoE) and also one may expect the mobile data caps to gradually increase in 2020s. Typical use cases for eMBB and business scenarios are ultra-broadband mobile Internet at homes and enterprises for all OTT (Over The Top) with better quality of experience than before due to higher speeds and lower delays, then fixed wireless access (FWA), 5G broadcast (including broadcast to $5 \mathrm{G}$ devices without SIM cards), AR (Augmented Reality), VR (Virtual Reality), XR (Any Reality), as well as video with ultra high resolutions $(4 \mathrm{~K}, 8 \mathrm{~K})$ which is foreseen as dominant type of e MBB mobile traffic.

Considering the above use cases, regarding the business aspects, in $5 \mathrm{G}$ era the mobile operator can have different roles, which include network developer, service enabler (toward third parties via 5G Core network APIs), and service creator (for new services offered either to individual users with QoS guarantees, or to different business users in different industries). The expectations are the largest increase 
of 5G revenues (not largest revenues, but only largest increase) to come from digitization of manufacturing as well as energy utilities.

Which mobile technology will be dominant in the first half of 2020s? That will be the LTE in all of its flavors (LTE, LTE-Advanced, and LTEAdvanced Pro), [14-15]. So, 4G LTE will pay the bills for all early $5 \mathrm{G}$ deployments, in the same manner as $3 \mathrm{G}$ has done it for $4 \mathrm{G}$ deployments around 2010. In the same manner, one may expect that $5 \mathrm{G}$ will pay the price for early $6 \mathrm{G}$ deployments in early 2030s. Then, let take a high-level look for possible expectations beyond $5 \mathrm{G}$ in the following section of this paper.

\section{BEYOND 5G - EARLY 6G VIEWPOINTS}

Academia has already started to look beyond 5G and to conceptualize 6G. Machine learning based on Big Data and clouds is promising to enter later into the $5 \mathrm{G}$ world. Considering the $\mathrm{AI}$ momentum again in the telecom/ICT world, one may expect $\mathrm{AI}$ to be used for design and optimization of future $6 \mathrm{G}$ network, including the protocols and their operations. Vision of $6 \mathrm{G}$ is evolution from connected things to connected intelligence with possible requirements of aggregate data rates up to 1 Tbit/s or perhaps less (it is not early for exact estimations), high-energy efficiency that will support battery free IoT devices (e.g., use of energy harvesting), massive low latency control (as contrast to 5G where it is just emerging) and connected intelligence with machine learning capability. Some expectations go beyond the $5 \mathrm{G}$ use cases (eMBB, URLLC and mMTC) and some possible beyond 5G use scenarios include computation oriented communication [19], contextually agile eMBB communication targeted to provision of eMBB services more agile and adaptive to the network context. Software Defined Network (SDN) and Network Function Virtualization (NFV) shall continue to be main approaches also in $6 \mathrm{G}$, together with network APIs for network programmability regarding the creation of new services by the third parties (i.e. parties different than mobile operators). In $5 \mathrm{G}$ network slicing provides powerful virtualization capability to allow multiple logically isolated/separated networks to be created on top of a shared physical infrastructure. In that manner $6 \mathrm{G}$ may continue towards massive network slicing, with numerous network slices (each slices defined for each micro- or macro-service). With such developments, the complexness of the network increases beyond the traditional computa- tional approaches used in past mobile generations (and also used for 5G, at least in the first deployments). So, the use of AI based on Big Data collected from different network functions in different contexts (e.g., provider, service, users, time, location, quality, security, etc.) will become necessity with aim network entities to support diverse capabilities for different services. Looking into the radio part, and considering that NR is in fact extension of the LTE radio approaches with additional numerologies for different frequency bands, one may expect such further extensions of the numerologies to result into, let name it here, 6G Radio (6GR) access (based on many new numerologies in different frequency bands, from $\mathrm{MHz}$ to hundreds of $\mathrm{GHz}$ and even $\mathrm{THz}$, based on massive MIMO with hundreds of antennas, and new modulation and coding schemes). AI-assisted IoT services, data collection, analytics and storage should be native in 6G era. One may say that the late 5G (e.g., "real" URLLC services and many network slices on the ground, together with massive use of mmWave bands) will in fact be the early $6 \mathrm{G}$.

\section{CONCLUSION}

Mobile technology rapidly evolves with a new mobile generation in each decade, going from $1 \mathrm{G}$ in 1980 s to $5 \mathrm{G}$ in 2020 s. Every successor mobile generation offers improved and advanced features compared to its predecessor. There is availability of different mobile generations on the telecom market, starting with $2 \mathrm{G}$ (e.g., GSM), via $3 \mathrm{G}$ (e.g., UMTS) and 4G (e.g., LTE/LTE-Advanced/LTE-Advanced Pro) to 5G deployments. The main and probably the only one that will be massively deployed in 2020s is coming from 3GPP, starting with $3 \mathrm{GPP}$ release 15. The $5 \mathrm{G}$ introduces New Radio (NR) by adding new numerologies to existing LTE radio interfaces in sub- $6 \mathrm{GHz}$ bands and also in mmWave bands above $24 \mathrm{GHz}$. The main novelty is network function virtualization and network softwarization, which means that 5G Next Generation Core and 5G NR access network are built by using different functions in separated user and control plane. That provides the network slicing approach, with three main service types seen for the $5 \mathrm{G}$ era, eMBB, mMTC and URLLC, which may be provided via separate network slices as logically separated network partitions. From the business point of view the initial driver will be the eMBB, then mMTC and lastly the most demanding and also the most distinguishing one, the URLLC use case which is tailored to 
provide various mission-critical services (e.g., discrete automation). Many $5 \mathrm{G}$ network functions also exposed to third parties via RESTful APIs, to different Over-The-Top (OTT) service providers, which provides possibilities for new business relations between different players in the mobile value chain (providers, telcos, user and vendors). Higher speeds and higher capacity in mobile networks with $5 \mathrm{G}$ and beyond results in constantly increasing mobile traffic and number of connected devices. That triggers the need for use of Machine Learning and other Artificial Intelligence (AI) in $5 \mathrm{G}$ and future mobile networks, such as 6G in 2030s.

\section{REFERENCES}

[1] Janevski, T.: QoS for Fixed and Mobile Ultra-Broadband, John Wiley \& Sons, Wiley-IEEE series, UK, April 2019.

[2] Janevski, T.: Internet Technologies for Fixed and Mobile Networks, Artech House, USA, November 2015.

[3] Janevski, T.: NGN Architectures, Protocols and Services, John Wiley \& Sons, April 2014. [1]

[4] ITU: Setting the Scene for 5G: Opportunities \& Challenges, 2018.

[5] Recommendation ITU-T Y.3101, Requirements of the IMT-2020 Network, January 2018.
[6] ITU Recommendation Y.3130, Requirements of IMT-2020 fixed mobile convergence, January 2018.

[7] 3GPP: NG Radio Access Network (NG-RAN), 2018.

[8] 3GPP: RESTful APIs for the 5G Service Based Architecture, 2018.

[9] 3GPP TS 23.501 V15.1.0: System Architecture for the 5G System; Stage 2 (Release 15), March 2018.

[10] 3GPP TS 23.501 version 15.3.0 Release 15, System Architecture for the 5G System, September 2018.

[11] 3GPP TS 38.300 version 15.5.0 Release 15, 5G; NR; Overall description; Stage-2, March 2019.

[12] 3GPP TR 21.915, V15.0.0, Release 15, Description; Summary of Rel-15 Work Items (Release 15), September 2019.

[13] IETF RFC 8041, Use Cases and Operational Experience with Multipath TCP, January 2017.

[14] GSMA Intelligence, Global Mobile Trends, September 2018.

[15] GSMA, The Mobile Economy 2018, 2018.

[16] ITU Recommendation Y.3103, Business role-based models in IMT-2020, September 2019.

[17] ITU Recommendation Y.3111, IMT-2020 network management and orchestration framework, September 2018.

[18] ETSI, MEC in $5 G$ networks - First edition, June 2018.

[19] Letaief, K. B., Chen, W., Shi, Y., Zhang, J., Zhang, Y. A.: The Roadmap to 6G: AI Empowered Wireless Networks, IEEE Communications Magazine, vol. 57, no. 8, August, 2019, DOI: 10.1109/MCOM.2019.1900271. 
